SHS Web of Conferences 10, 00003 (2014)

DOI: $10.1051 /$ shsconf/20141000003

C Owned by the authors, published by EDP Sciences, 2014

\title{
The reimbursement for the medical treatment expenses within the framework of Roman Partnership Agreement (Societa)
}

\author{
A. Apsitis \\ Rīga Stradiòš University, Latvia
}

\begin{abstract}
The report is the presentation of the results of research performed by the author on the primary sources of Roman law in relation to the situation regarding the reimbursement for the medical treatment within the framework of Roman Partnership (societa - Latin) Agreement. It is pointed out that a partner of Partnership was entitled to recover expenses from the fellow partner, if the expenses were due to common interests of Partnership and were the result of Partnership's business activities or related to such business activities. It is also pointed out that the Roman law had rather complicated regulating functions regarding the material responsibility of a medical practitioner, who had provided medical treatment, for the quality and results of treatment, as well as the medical practitioner's remuneration, status and privileges resulting from this status.
\end{abstract}

\section{Introduction}

The research has been performed as a separate element of the author's studies on the primary sources of Roman Private Law; the studies were carried out within the process of the development of doctoral thesis "The Terms of Capital Consolidation in the Roman Law". According to the information at the author's disposal, the researchers from Latvia have not studied the topic from this point of view; the author has found no publications in Latvian. Thus, the research could become a certain contribution to the development of the national science of law. The aim - to study the terms of the mutual reimbursement for the medical treatment expenses in relation to the institution of the Roman Partnership (societa Latin) Agreement.

\section{Materials and methods}

Within the research, studies and analysis of the primary sources of Roman Private Law were carried out (The Institutes of Justinian (Iustiniani Institutiones) (Krueger 1928), the Digest (Digesta) (Krueger; Mommsen 1928) and The Code of Justinian (Codex Iustinianus) (Krueger 1906)), mostly by applying the inductive, deductive and comparative methods.

This is an Open Access article distributed under the terms of the Creative Commons Attribution License 4.0, which permits unrestricted use, distribution, and reproduction in any medium, provided the original work is properly cited. 
SHS Web of Conferences

\section{Results, discussion}

If a participant of Roman Partnership Agreement - a partner of Partnership (societa - Latin) had spent anything for the business needs of the Partnership, he could apply to the co-partners and claim the reimbursement of expenses (D 17.2.67 pr.).

In conformity with the general principle, the property of the Partnership, established by the partners was owned by all the partners jointly, and each of the partners could recover any expenses spent in favour of the property of the Partnership (D 17.2.38.1). Thus, the partner has the right to claim, for example, the rational reimbursement for travel expenses. He was entitled to the reimbursement of expenses spent for the hotel services and rent of pack animals and vehicles - for the transportation of both the partner and Partnership's goods, including also the expenses spent for the packing of goods (D 17.2.52.15).

In the case of the recovery of expenses, the partners were entitled to collect the interest. This applied to the cases, when the partner had spent the money he had borrowed according to the interest rate and when he had spent his own money. The partner could claim the interest he could gain for lending somebody money (D 17.2.67.2). According to the modern terminology, the average credit interest existing in the money lending market was taken into account.

In relation to the reimbursement for the partners' medical treatment expenses, we can find particular terms in the sources of Roman Law. Thus, for example, in Digest 17, Title 2 Pro socio there is viewed a situation, when a member of the Partnership is wounded, while he is trying to prevent the escape of slaves owned by the Partnership.

Labeo (Marcus Antistius Labeo, the of the $1^{\text {st }}$ century BC/the beginning of the $1^{\text {st }}$ century AD), the Roman lawyer, said in relation to this case that the expenses spent for the medical services cannot be recovered, because they were not caused as a result of Partnership's business activities, although they were spent in relation to such activities.

But Iulianus (Salvius Iulianus, the $2^{\text {nd }}$ century AD), the lawyer, has expressed a view that the wounded partner in such cases could receive the reimbursement for the expenses spent on medical services. And it is correct (D 17.2.61). Thus the wounded was entitled to the reimbursement for the medical treatment expenses.

Similarly, a situation was described, when two partners had established a Partnership with the aim of making the cloaks for soldiers, and one of the partners went on a trip to purchase the raw material, but during the trip he suffered from the attack of robbers. His money was stolen, the slaves wounded, and the partner lost not only the Partnership's property, but also his own property. In this case, if the victim's real aim was the purchase of goods for Partnership's business needs, then, according to Iulianus (Salvius Iulianus, the $2^{\text {nd }}$ century AD), the lawyer, the other partner shall share the expenses spent for the payment to the medics (D 17.2.52.4).

Of course, the victim always had the right to bring a claim against the robbers - the people who committed the robbery (rapina - Latin). It should be pointed out that there have been two, to a certain extent similar, unlawful offences or delicts (delicta - Latin) identified in Roman law - theft (furtum Latin) and robbery (rapina - Latin).

According to the ancient Romans' point of view, "a theft is the deceitful misappropriation of a thing, its usage or possession, which is prohibited by natural rights" (Furtum est contrectatio rei fraudulosavel ipsus rei vel eitam usus eius possessioionisve, quod lege naturali proxibitum est admittere - Latin) (I 4.1.1).

Unlike robbery (rapina - Latin), which meant dispossession of another person's property misappropriation it by force ("A shameless theft") (see I. 4.2 tit.), a theft (furtum - Latin) did not comprise the element of violence.

The above mentioned Roman tradition has been adopted also in modern criminal law, including the criminal law of the Republic of Latvia, where there are also similarly differentiated "a theft" - concealed 


\section{Int. Conf. SOCIETY. HEALTH. WELFARE.}

or overt stealing of the movable property of another (see The Criminal Law, Sect. 175) and a different offence according to its structure - "a robbery" - stealing of movable property of another associated with violence or threatened violence (see Criminal Law, Sect. 176) (Apsītis; Joksts 2013).

As concerns the institute of robbery (rapina - Latin) according to its Roman interpretation, its victim could bring a special claim (actio - Latin) against the guilty person; the claim was called vi bonorum raptorum (Latin). If the claim was brought within a period of one year after the robbery had been committed, the victim was entitled to claim the compensation in the fourfold amount of the value of dispossessed property. If the claim was brought after a year, when the robbery had been committed, the victim was entitled to claim for the compensation in the one-fold amount of the value of dispossessed property. It was particularly emphasized that the claim could be brought against anybody, who had misappropriated by force the property of another, even if it would be only one thing of the most insignificant value (I 4.2 pr.).

Besides, the victim, who brought the claim, might not be also the legal owner of the misappropriated property, but this person could have the particular property on another legal basis - in conformity with the lease, deposit or other (including partnership) contract, as an object of pledge etc. (I 4.2.2).

Let us return to the above mentioned case viewed by Roman lawyers, when the partnership partner's slaves, who had been wounded during robbery (rapina - Latin), were provided medical treatment (D 17.2.52.4). It is necessary to point out that the doctor, who provided medical treatment for slaves, in this case was responsible for the appropriate fulfilment of his duties and, if his actions turned out to be unprofessional, there could be an action brought against him in conformity with so-called Aquilian Law (Lex Aquilia - Latin). Thus, the doctor was responsible for the slave's death as a result of unprofessionally performed operation or the application of mistakenly chosen medicine (I 4.3.7), or in a situation, when the doctor had performed an operation and then neglected further medical treatment of the slave, and due to that the slave died (I 4.3.6).

It was assumed that the doctor had committed the violation of rights - the delict (delicta - Latin), and the owners of the slave could bring against him a special claim actio damni iniuriae (Latin). The claim had to be brought against everybody, who had wrongfully killed another's slave or a four-footed herd animal, and that meant the guilty person had to pay the compensation in the amount of the highest value of slave of four-footed animal whatever it was in the preceding year (I 4.3.pr.). Namely, there had to be taken into consideration the highest value of the thing it had in the preceding year. Thus, if the doctor killed the slave, who was lame, disabled or had only one eye at the moment he died, but who was considered to be healthy during the preceding year and of significant value, the guilty medic had to cover the highest value of the slave in the preceding year, instead of the slave's real value.

The guilty doctor, in this case, in fact, covered not only the direct damage he caused, but was also punished accordingly in the amount of the highest possible penalty. It should be pointed out that, if the doctor died, in conformity with Aquilian Law (Lex Aquilia - Latin), the responsibility was not passed over to his heirs (I 4.3.9).

When describing the doctor's status in conformity with Roman legal system, it should be emphasized that doctors (medici - Latin) were considered the persons engaged in so-called "liberal arts" (ars liberalis - Latin) or professions and, therefore initially their services were not compensated. However, doctors could demand the remuneration for work performed, if they had fulfilled their duties in compliance with a contract - so-called locatio conductio operarum (Latin) or a contract for hiring of services (Berger 1953; 1991).

In relation to late Roman empire it is known about the remuneration provided by state or local government. In conformity with the law passed by Constantine the Great (Flavius Valerius Aurelius Constantinus Augustus, 272 - 337 AD), the Roman Emperor, in 333 AD, the medics (medici Latin) and especially - the chief medics of a particular community (archiatri - Latin), as well as the former chief medics had to be paid wages and remunerations, in order they would improve their skills in liberal arts more willingly (C 10.53.6.1). It is also known about the population's contributions 
(annonaria - Latin) for the purposes of supporting chief medics (C 10.53.9 pr.) and about the remuneration given by patients (C 10.53.9.1).

According to the Roman legal views, a medic was a person, who promised to take care of any part of the human body or to free a person from pain, for example, inflammation of the ear, fistula or toothache. At the same time it was envisaged that a medic shall not use incantations, curses, exorcism and similar methods - they shall not be attributed to the engagement in medical activities, although some people praise the above mentioned techniques and are ready to confirm that have had benefit from them (D 50.13.1.3).

The midwives were also considered as medical persons (D 50.13.1.2), as well as professors of medicine, because they take care of a human health, but the professors of medicine - of the education of medics and studies of medicine (D 50.13.1.1).

In order to become a new chief medic (archiater - Latin) instead of the late chief medic, the medic's qualification had to be evaluated by seven or more leading medics. Besides, everybody, who worked in this profession, could not be immediately designated for the first degree, but he had to take his place and be the last in the queue, behind those, who were there before him (C 10.53.10).

In order to be involved in teaching (docere - Latin), the person had to receive the consent of the most significant citizens and be accepted by the local government of community by means of accordingly passed decree (decretum curialium - Latin) (C 10.53.7.1).

Medic's status guaranteed certain, quite often - significant, privileges. In the late Roman empire, the medics were exempted from the mandatory and often heavy corvée imposed on the population of empire in state's favour (munera - Latin). There existed a rule that medics (medici - Latin) and chief medics (archiatri - Latin), as well as former chief medics together with their wives, children and any possessed property shall be exempted from any tasks and any responsibilities, private or public, they shall not be forced to house the guests, do any type of work, give away things they possess, suffer any offence etc. Anybody, who would solicit with such tasks, had to be punished in compliance with the judgement passed by a judge (C 10.53 .6 pr.). It was provided that the medics shall not be offended by the clerks and officials of local governments, irrespective of the fact, whether the medics have finished or started to fulfil their duties, or have received honourable exemption from the fulfilment of duties. There was particularly emphasized that medics and their family members shall not be forced to house soldiers and judges (C 10.53.11 pr.), as well as that all the above mentioned privileges shall be related to medics' children and wives (C 10.53.11.1), and to the professors, including professors of medicine, and their children (C 10.53.11.2).

At the same time it is known that not all medics had such privileges. In the sources of Roman law we can find a reference to the situation, when a person serves as a medic in the Roman army - while he is serving to the state being involved in the military service, the medic shall not be forced to fulfil any corvée an individual is bound to fulfil (munera civilia - Latin). When the medic shall discontinue to serve in the army, he will be given the right to be exempted from the fulfilment of corvée, but only in the case, if he would be included among the medics, who had been bestowed this privilege (C 10.53.1) - a decision (decreta - Latin) on the exemption was made by the respective community's local government (decuriones (Latin) - municipal senate), and no medic had to be exempted from the fulfilment of corvée (munera - Latin) against the will of local government - decurions (decuriones - Latin) ( C 10.53.5).

The status of a medic, particularly - the status of a medic employed at the emperor's palace, could ensure special honour and receiving of different honorary titles (C 10.53.11 pr.).

At the same time, the ethical priorities of a medic were indicated. For example, it is emphasized in the sources of Roman law that the community's chief medics (archiatri lat.) have to be aware - it is more honourable to help the poor than to serve mainly to the rich people. (C $10.53 .9 \mathrm{pr}$.) It was also pointed out that a medic is entitled to receive only the remuneration offered by patients, and the medics must not misuse the situation and demand the things from the patient that had been promised for the renewal of health under the conditions of jeopardy (C 10.53.9.1). 


\section{Int. Conf. SOCIETY. HEALTH. WELFARE.}

Finally - the representatives of liberal arts “... first of all have to be eminent in relation to their morals, then - rhetoric" (. . excellere oportet moribus primum, deinde facundia - Latin) (C 10.53.7 pr.).

\section{Conclusions}

The partners of Roman Partnership (societa - Latin) were entitled to the mutual reimbursement of expenses, if those expenses were spent in favour of the common interests of Partnership (D 17.2.38.1; D 17.2.52.15; D 17.2.67 pr.; D 17.2.67.2).

The medical treatment expenses as a result of Partnership's business activities or in relation to such business activities were acknowledged as one of the types of expenses to be mutually reimbursed (D 17.2.52.4; D 17.2.61).

Roman medics, performing medical treatment, were financially responsible for the quality and results of medical treatment provided - operations, choice of medicine, post-operational care etc. (I 4.3.pr.; I 4.3.6; I 4.3.7; I 4.3.9).

In the beginning, the services provided by medics or the representatives of so-called "liberal arts" or professions (ars liberalis - Latin) legally did not envisage for the obligatory remuneration of a medic. The medics could demand for the remuneration, if they had acted within the framework of a preliminary concluded contract. The late Roman empire is characteristic of the involvement of medics in the structures ensuring public administration and functioning, and there was the system for the remuneration of medics, which was organized by state power, alongside with it there were the patients' payments for the medical treatment received (C 10.53.6.1; C 10.53.9 pr.; C 10.53.9.1).

Roman law envisaged the differentiation between the medics - professionals (D 50.13.1.2; D 50.13.1.3) and different quacks and those applying "unconventional" treatment methods (D 50.13.1.3).

The sources of Roman law present the existence of the origins of system for the education and qualification evaluation of medics at least in the late Roman empire (D 50.13.1.1; C 10.53.7.1; C 10.53.10).

The profession of a medic was honourable (C 10.53.11 pr.) and ensured different privileges and allowances both to the representative of this profession (C 10.53.6 pr.; $C 10.53 .11 \mathrm{pr}$.) and to his family members (C 10.53.6 pr.; C 10.53.11.1; C 10.53.11.2). However, receiving of privileges and allowances depended from the attitude of local community and its government (C 10.53.1; C 10.53.5).

The medic had to observe legally defined moral and ethical regulations (C 10.53.7 pr.; C 10.53.9 pr.; C 10.53.9.1).

\section{References}

[1] Apsītis, A., Joksts, O. (2013) Noziedzīgs nodarījums zādzība (furtum) romiešu tiesību kontekstā [Offence of Theft (furtum - Latin) In The Context of Roman Law] . Administratīvā un Kriminālā Justīcija, 2013., 1 (62), 7 , ISSN 1407-2971 (in Latvian)

[2] Berger, A. (1953; 1991) Encyclopedic Dictionary of Roman Law. Philadelphia: The American Philosophical Society, pp. 579-580

[3] Krueger, P. (ed.) (1906) CORPUS IURIS CIVILIS, EDITIO STEREOTYPIA OCTAVA, VOLUMEN SECUNDUM, CODEX IUSTINIANUS, RECOGNOVIT PAULUS KRUEGER [Body of Civil Law. Eighth Stereotype Edition. Second Volume. The Code of Justinian . Revised by Paul Krueger.]. BEROLINI: APUD WEIDMANNOS [Berlin: Weidmannos ]. pp. 422-423 (in Latin), Available on the Internet: http://fama2.us.es/fde/ocr/2007/corpusIurisCivilisCodexIustinianus.pdf, pp. 452-453

[4] Krueger, P. (ed.) (1928) IUSTINIANI INSTITUTIONES [Institutes of Justinian]. In Krueger, P., Mommsen, T. (eds.) CORPUS IURIS CIVILIS, EDITIO STEREOTYPIA QUINTA DECIMA, 
VOLUMEN PRIMUM, INSTUTIONES, RECOGNOVIT PAULUS KRUEGER, DIGESTA, RECOGNOVIT THEODORUS MOMMSEN, RETRACTAVIT PAULUS KRUEGER, [Body of Civil Law. Fifteenth Stereotype Edition . First Volume. Institutes, Revised by Paul Krueger. Digest, Revised by Theodore Mommsen, Reworked by Paul Krueger]. (43 pp.). BEROLINI: APUD WEIDMANNOS [Berlin: Weidmannos] (in Latin).

Available on the Internet:

http://fama2.us.es/fde/ocr/2006/corpusIurisCivilisT1InstitutionesDigesta.pdf, 66 pp.; Ibid. (45 pp.) Available on the Internet:

http://fama2.us.es/fde/ocr/2006/corpusIurisCivilisT1InstitutionesDigesta.pdf, 68 pp.

[5] Krueger, P., Mommsen, T. (eds.) (1928) IUSTINIANI DIGESTA. [Digest of Justinian] In Krueger, P., Mommsen, T. (eds.) CORPUS IURIS CIVILIS, EDITIO STEREOTYPIA QUINTA DECIMA, VOLUMEN PRIMUM, INSTUTIONES, RECOGNOVIT PAULUS KRUEGER, DIGESTA, RECOGNOVIT THEODORUS MOMMSEN, RETRACTAVIT PAULUS KRUEGER [Body of Civil Law. Fifteenth Stereotype Edition . First Volume. Institutes, Revised by Paul Krueger. Digest, Revised by Theodore Mommsen, Reworked by Paul Krueger]. (pp. 257-259). BEROLINI: APUD WEIDMANNOS [Berlin: Weidmannos] (in Latin).

Available on the Internet:

http://fama2.us.es/fde/ocr/2006/corpusIurisCivilisT1InstitutionesDigesta.pdf, pp. 340-342; Ibid. (261pp.)

Available on the Internet:

http://fama2.us.es/fde/ocr/2006/corpusIurisCivilisT1InstitutionesDigesta.pdf,344 pp.Ibid. (907 pp.) Available on the Internet:

http://fama2.us.es/fde/ocr/2006/corpusIurisCivilisT1InstitutionesDigesta.pdf, 990 pp. 